\title{
Effect of Spacing and Nitrogen on Vegetative Growth and Flower Yield of Asiatic Lily CV. Tressor under Shade Net Condition
}

\author{
J. Swetha*, T. Suseela, A.V.D. Dorajeerao, D.R. Salomi Suneetha and R.V. Sujatha \\ College of Horticulture, Dr.Y.S.R.H.U, Venkataramannagudem, West Godavari (Dist.) - 534 \\ 101 (Andhra Pradesh), India \\ *Corresponding author
}

\section{A B S T R A C T}

\begin{tabular}{|l|}
\hline K e y w o r d s \\
Asiatic lily, \\
$\begin{array}{l}\text { Spacing, Nitrogen, } \\
\text { Flower yield and } \\
\text { shade net }\end{array}$ \\
\hline Article Info \\
\hline $\begin{array}{l}\text { Accepted: } \\
\text { 26 July 2018 } \\
\text { Available Online: } \\
10 \text { August } 2018\end{array}$ \\
\hline
\end{tabular}

\section{Introduction}

Lilium is one of the most fascinating ornamentals in appearance, beauty, different forms and hues of colours and it is a "low volume" high value crop. Lilium is one of the largest genera of flower bulbs produced world-wide. The genus lilium belongs to family Liliaceae and comprises of 100 species, including many beautiful ornamental species. Lilies are native to Northern - Hemisphere and are widely distributed over China, Japan, Siberia, South Canada and extending upto Florida in USA.

\begin{abstract}
A study was conducted to evaluate the effect of spacing and nitrogen on vegetative growth and flower yield of Asiatic lily cv. Tressor at College of Horticulture, Dr. Y.S.R. Horticultural University, Venkataramannagudem, West Godavari district, Andhra Pradesh during the rabi season of 2016-17. Results showed that minimum number of days to bulb sprouting was observed with $30 \mathrm{~cm} \times 15 \mathrm{~cm}$ and nitrogen at $200 \mathrm{~kg} \mathrm{ha}^{-1}$. The vegetative parameters like plant height, number of leaves, leaf area per plant and total chlorophyll content was recorded highest with a spacing of $30 \mathrm{~cm} \mathrm{x}$ $15 \mathrm{~cm}$ and nitrogen at $200 \mathrm{~kg} \mathrm{ha}^{-1}$ both individually and in combination except to leaf area index. The spike yield per plot and spike yield per $1000 \mathrm{~m}^{2}$ was maximum with spacing of $30 \mathrm{~cm} \times 15 \mathrm{~cm}$, nitrogen dose of $200 \mathrm{~kg} \mathrm{ha}^{-1}$ both individually and in combination.
\end{abstract}

Lilium has excellent keeping quality, fragrance and longer stem which fetches premium price in flower market. It has wide applicability in floral industry, mainly as flower and potted plants. Hence, it ranks fourth among the top ten bulbous cut flower of the world in Aalsmeer Auction market after tulip, gladiolus and narcissus (Anonymous, 1996). They have been long admired for their aesthetic qualities and often depicted as the symbol of purity and regality. In India, lilium is being commercially cultivated in different parts such as, The Nilgiris (Cooner, Kothagiri and Ooty) in an area of around 40 acres (1,60,000 sq.m), Kodaikanal, Shevroy Hills 
(Yercad), Kalvarayan Hills (Karumanthurai), Hosur, Himachal Pradesh i.e. under Shimla and Kullu condition, North Eastern States and Jammu and Kashmir etc.

Nutrients such as nitrogen play a major role in growth and development of plants (Scott, 2008). Nitrogen as an essential element that improves the chemical and biological properties of soil and thereby stimulates the production of higher yield in plants. Nitrogen is a constituent of protoplasm i.e. chlorophyll ' $a$ ' and ' $b$ ' and nucleic acids. Nitrogen plays an important role in the synthesis of protoplasm and primarily in the manufacture of amino acids to enhance the auxin activities which leads to increased meristematic activities have an important role in maximum vegetative growth and yield (Tisdale and Nelson, 1975). Optimum plant density is another important factor for high plant growth and yield. Spacing between plants is particularly important for the cultivation of Asiatic lily to maximize flower quality and quantity characteristics.

The cut flower trade of Asiatic lily is lagging behind in the local regions of AP, owing to the non-availability of quality planting material at larger scale. Therefore keeping in view the economic importance of the crop, the present study was undertaken with the objective i.e. study the effect of spacing and nitrogen levels on vegetative growth and flower yield of Asiatic lily cv. Tressor under shade net.

\section{Materials and Methods}

The present investigation was conducted at College of Horticulture, Dr.Y.S.R Horticultural University, Venkataramannagudem during 2016-2017. Which is located at $16^{\circ} 63^{\prime} 120^{\prime \prime} \mathrm{N}$ latitude and $81^{\circ} 27^{\prime} 568^{\prime \prime}$ E longitude and $34 \mathrm{~m}$ above MSL. It experiences hot humid summer and mild winters. The experimental soil was red sandy loam with good drainage and moderate water holding capacity with sand $70 \%$ of sand, silt $20 \%$ and clay $10 \%$. The soil $\mathrm{pH}$ is 6.32 and E.C. is $0.18 \mathrm{dS} \mathrm{m}^{-1}$. The experiment was conducted in a factorial randomized block design involving three levels of spacing i.e. $\mathrm{S}_{1}$ $(15 \mathrm{~cm} \times 15 \mathrm{~cm}), S_{2}(25 \mathrm{~cm} \times 15 \mathrm{~cm})$ and $S_{3}$ $(30 \mathrm{~cm} \times 15 \mathrm{~cm})$ and three levels of nitrogen viz. $\mathrm{N}_{1}\left(100 \mathrm{~kg} \mathrm{ha}^{-1}\right), \mathrm{N}_{2}\left(150 \mathrm{~kg} \mathrm{ha}^{-1}\right)$ and $\mathrm{N}_{3}$ $\left(200 \mathrm{~kg} \mathrm{ha}^{-1}\right)$. Each of these factors was composed at three levels involving totally 9 treatment combinations.

Bulbs of Asiatic lily cv. Tressor with uniform size were used for the experiment. The net size of plot was $3.0 \mathrm{~m} \quad \mathrm{x} \quad 0.6 \mathrm{~m}$, accommodating 40, 24 and 20 plants as per treatments. The field was brought to the fine tilth by ploughing and harrowing. Well decomposed farm yard manure at the rate of $100 \mathrm{~kg} \mathrm{ha}^{-1}$ was applied at the time of land preparation. The fertilizers viz., Urea, Single Super Phosphate and Muriate of Potash were taken as the sources of $\mathrm{N}, \mathrm{P}_{2} \mathrm{O}_{5}$ and $\mathrm{K}_{2} \mathrm{O}$ respectively. Entire dose of phosphorus and potassium was given basally and half of the nitrogen at different graded levels is applied before planting and remaining dose of nitrogen applied as top dressing at 30 and 45 days after planting to the respective plots. Bulbs of Asiatic lily cv. Tressor were selected treatment wise and planted in the beds on $20^{\text {th }}$ October, 2016. The various observations on vegetative growth, floral, vase life and bulb parameters were recorded on five plants randomly selected from net plot area and tagged. The data collected for all the characters studied were subjected to statistical analysis by adopting 'Analysis of Variance' (ANOVA) technique for factorial randomized block design as suggested by Panse and Sukhatme (1967).

\section{Results and Discussion}

Data presented in Table 1 and 2 showed that the different levels of spacing and nitrogen significantly affected the vegetative growth 
parameters during the course of investigation. The early sprouting of bulbs (12.53 days) was recorded by $S_{3}(30 \mathrm{~cm} \times 15 \mathrm{~cm})$ and the maximum number of days for sprouting (14.17 days) was noted in $S_{1}$ spacing (15 $\mathrm{cm} \mathrm{x}$ $15 \mathrm{~cm})$. The minimum number of days taken for bulb sprouting (12.51 days) was observed in $\mathrm{N}_{3}\left(200 \mathrm{~kg} \mathrm{ha}^{-1}\right)$ whereas, the maximum delay in sprouting (14.68 days) was observed in $\mathrm{N}_{1}\left(100 \mathrm{~kg} \mathrm{ha}^{-1}\right)$. Among interaction effects, the combination of $\mathrm{S}_{3} \mathrm{~N}_{3}$ recorded early sprouting (11.66 days) and it was on par with the same spacing supplied with nitrogen at $150 \mathrm{~kg} \mathrm{ha}^{-1}\left(\mathrm{~S}_{3} \mathrm{~N}_{2}\right)$ (11.80 days) while the maximum number of days required for sprouting (15.33 days) was recorded by $\mathrm{S}_{1} \mathrm{~N}_{1}$. These results are in accordance with the findings of Singh and Singh (2005) in tuberose cv. Double and Sheoran et al., (2015) in tuberose cv. Prajwal.

The early sprouting under wider spacing can be ascribed to availability of sufficient space and better nutrient availability to the bulbs. The above results are in conformity with the results of Singh and Kumar (1999) in tuberose.

Shortening of days taken for initiation of sprouting with the application of higher nitrogen may be due to early absorption of nitrogen through the surface of bulbs or by primary roots (Sheoran et al., 2015). These results are in accordance with the findings of Singh and Uma (1996) in tuberose cv. Shringar, Kumar and Singh (1998) in tuberose, Rajwal and Singh (2006) in tuberose and Gangwar et al., (2012) in tuberose.

Regarding plant height (Table 1), maximum plant height $(46.08 \mathrm{~cm})$ recorded by $S_{3}(30 \mathrm{~cm}$ $\mathrm{x} 15 \mathrm{~cm})$ and the minimum $(41.89 \mathrm{~cm})$ was observed in $S_{1}(15 \mathrm{~cm} \mathrm{x} 15 \mathrm{~cm})$. Maximum plant height $(44.89 \mathrm{~cm})$ was observed in $\mathrm{N}_{3}$ (200 $\mathrm{kg} \mathrm{ha}^{-1}$ ) whereas, the minimum plant height $(42.84 \mathrm{~cm})$ was recorded in $\mathrm{N}_{1}(100 \mathrm{~kg}$ $\left.\mathrm{ha}^{-1}\right)$. Interaction effect was found to be highest in the combination of $\mathrm{S}_{3} \mathrm{~N}_{3}$ (47.07 $\mathrm{cm})$, and it was on par with the combination of $\mathrm{S}_{3} \mathrm{~N}_{2}(46.64 \mathrm{~cm})$ whereas, minimum value for plant height $(41.06 \mathrm{~cm})$ was recorded by $\mathrm{S}_{1} \mathrm{~N}_{1}$. Similar results were found by Vedavathi et al., (2014) in Asiatic lily (Lilium spp.).

The increase in plant height with wider levels of spacing might be due to less competition for nutrients, optimum plant population per unit area and all the plants received proper amount of sun light, aeration and nutrition for maximum vegetative growth (Sudhakar and Kumar, 2012).

The maximum plant height obtained at higher doses of nitrogen on different days after planting revealed that nitrogen had an encouraging effect on plant height as it forms an important constituent of protein, which is essential for the formation of protoplasm thus affecting the cell division and cell enlargement and ultimately leads to better vegetative growth (Sheoran et al., 2015). These results are in confirmation with the findings of Kishore and Singh (2006) in tuberose cv. Single and Das et al., (2011) in tuberose.

Data showed that different levels of spacing and nitrogen significantly affected number of leaves (Table 1). The maximum number of leaves (73.27) recorded by $\mathrm{S}_{3}(30 \mathrm{~cm} \times 15 \mathrm{~cm})$ and was on par with $S_{2}(25 \mathrm{~cm} \times 15 \mathrm{~cm})$ (72.28) and minimum number of leaves (63.60) observed in $S_{1}(15 \mathrm{~cm} \times 15 \mathrm{~cm})$. Maximum number of leaves (71.85) observed in $\mathrm{N}_{3}\left(200 \mathrm{~kg} \mathrm{ha}^{-1}\right)$ and was on par with $\mathrm{N}_{2}$ $\left(150 \mathrm{~kg} \mathrm{ha}^{-1}\right)$ (69.51) whereas, the minimum number of leaves (67.79) was recorded in $\mathrm{N}_{1}$ $\left(100 \mathrm{~kg} \mathrm{ha}^{-1}\right)$. With respect to interaction, combination of $\mathrm{S}_{3} \mathrm{~N}_{3}$ was found to show the maximum number of leaves (75.00) and was on par with $\mathrm{S}_{2} \mathrm{~N}_{3}$ (74.66) while the minimum number of leaves (61.92) was registered by $\mathrm{S}_{1} \mathrm{~N}_{1}$. The present results are in conformity with the earlier findings of Singh and Singh (2005) in tuberose cv. Double and Vedavathi 
et al., (2014) in Asiatic lily (Lilium spp.). From the above results, it is revealed that, number of leaves per plant was highest under wider spacing $S_{3}(30 \mathrm{~cm} \times 15 \mathrm{~cm})$. It could be due to availability of more space facilitating improved aeration and better penetration of light which in turn might have increased photosynthetic activity and translocation of assimilates to growing parts resulting in better availability of nutrients (Ram et al., 2012). These results are in accordance with the findings of Mukopadhyay and Yadav (1984) in gladiolus.

An increase in number of leaves with the application of higher doses of nitrogen might be due to the fact that nitrogen is an essential part of nucleic acid which plays a vital role in promoting the plant growth and number of leaves (Patel et al., 2006). Similar findings were reported by Banker (1990) and Mukopadhyay (1990) in tuberose and Jana et al., (1974) in dahlia and tuberose.

Regarding leaf area per plant (Table 2), maximum leaf area $\left(758.02 \mathrm{~cm}^{2}\right)$ obtained with $S_{3}(30 \mathrm{~cm} \times 15 \mathrm{~cm})$ and it was on par with $\mathrm{S}_{2}\left(750.75 \mathrm{~cm}^{2}\right)$ while the minimum leaf area $\left(670.18 \mathrm{~cm}^{2}\right)$ was observed in $\mathrm{S}_{1}(15 \mathrm{~cm} \mathrm{x}$ $15 \mathrm{~cm})$. Maximum leaf area $\left(734.72 \mathrm{~cm}^{2}\right)$ was observed in $\mathrm{N}_{3}\left(200 \mathrm{~kg} \mathrm{ha}^{-1}\right)$ and it was on par with $\mathrm{N}_{2}\left(150 \mathrm{~kg} \mathrm{ha}^{-1}\right)\left(727.75 \mathrm{~cm}^{2}\right)$ whereas, the minimum leaf area $\left(716.49 \mathrm{~cm}^{2}\right)$ was recorded in $\mathrm{N}_{1}\left(100 \mathrm{~kg} \mathrm{ha}^{-1}\right)$. The interaction effect was also found to be significantly superior in the combination of $\mathrm{S}_{3} \mathrm{~N}_{3}$ (767.55 $\mathrm{cm}^{2}$ ) which was on par with $\mathrm{S}_{2} \mathrm{~N}_{3}$ (759.08 $\left.\mathrm{cm}^{2}\right)$ and $\mathrm{S}_{3} \mathrm{~N}_{2}\left(758.71 \mathrm{~cm}^{2}\right)$ while the minimum value for leaf area $\left(661.44 \mathrm{~cm}^{2}\right)$ was registered by $S_{1} N_{1}$.

More number of leaves and more leaf area were obtained at wider spacing because the plants grow vigorously without much competition for nutrients which might have favoured more photosynthesis for higher yield (Karthikeyan and Jawaharlal, 2013). Similar results were also obtained by Shiraj and Maurya (2005) in gladiolus.

Increase in leaf area with higher doses of nitrogen application might be due to the fact that, increased photosynthetic ability had positive influence on growth parameters (Rathore and Singh, 2013).

Data shown in Table 2 reveals that different spacing and nitrogen doses significantly affected leaf area index. The highest leaf area index (2.97) was registered by $\mathrm{S}_{1}(15 \mathrm{~cm} \times 15$ $\mathrm{cm})$ and the lowest leaf area index (1.68) was observed in $\mathrm{S}_{3}(30 \mathrm{~cm} \times 15 \mathrm{~cm})$. Application of nitrogen at $\mathrm{N}_{3}$ level $\left(200 \mathrm{~kg} \mathrm{ha}^{-1}\right)$ was found to record the maximum leaf area index (2.24) whereas, the minimum leaf area index (2.18) was observed in $\mathrm{N}_{1}\left(100 \mathrm{~kg} \mathrm{ha}^{-1}\right)$. Among interaction effects, the combination of $\mathrm{S}_{1} \mathrm{~N}_{3}$ was found to show the highest leaf area index (3.01) followed by $\mathrm{S}_{1} \mathrm{~N}_{2}$ (2.98) whereas, $\mathrm{S}_{3} \mathrm{~N}_{1}$ recorded minimum leaf area index (1.66). Similar results were found by Khobragade et al., (2012) in China aster cv. Poornima and Chandana and Dorajeerao (2014) in gladiolus cv. White Prosperity.

Leaf area index decreases with wider levels of spacing (Khobragade et al., 2012) in China aster cv. Poornima under Indore conditions.

Leaf area index increases with application of higher doses of nitrogen (Chandana and Dorajeerao, 2014) in gladiolus cv. White Prosperity under Venkataramannagudem conditions.

Regarding total chlorophyll content (Table 2), maximum chlorophyll content (50.47) was obtained by $S_{3}(30 \mathrm{~cm} \times 15 \mathrm{~cm})$ and the minimum value for chlorophyll content (44.43) was noted in $S_{1}(15 \mathrm{~cm} \mathrm{x} 15 \mathrm{~cm}) . \mathrm{N}_{3}$ (200 $\mathrm{kg} \mathrm{ha}^{-1}$ ) recorded the maximum chlorophyll content (49.10) whereas, minimum chlorophyll content (46.46) was registered by $\mathrm{N}_{1}\left(100 \mathrm{~kg} \mathrm{ha}^{-1}\right)$. 
Table.1 Days to bulb sprouting, plant height and number of leaves as influenced by spacing, nitrogen levels and their interaction in Asiatic lily cv. Tressor under shade net condition

\begin{tabular}{|c|c|c|c|c|c|c|c|c|c|c|c|c|}
\hline \multirow[t]{3}{*}{ Nitrogen $\left(\mathrm{kg} \mathrm{ha}^{-\mathbf{1}}\right)$} & \multicolumn{4}{|c|}{ Days to bulb sprouting (d) } & \multicolumn{4}{|c|}{ Plant height (cm) } & \multicolumn{4}{|c|}{ Number of leaves } \\
\hline & \multicolumn{3}{|c|}{ Spacing $(\mathrm{cm})$} & \multirow{2}{*}{ Mean } & \multicolumn{3}{|c|}{ Spacing $(\mathrm{cm})$} & \multirow{2}{*}{ Mean } & \multicolumn{3}{|c|}{ Spacing $(\mathrm{cm})$} & \multirow{2}{*}{ Mean } \\
\hline & $\mathrm{S}_{1}$ & $\mathrm{~S}_{2}$ & $\mathrm{~S}_{3}$ & & $\mathrm{~S}_{3}$ & $\mathrm{~S}_{2}$ & $\mathrm{~S}_{3}$ & & $\mathrm{~S}_{3}$ & $\mathrm{~S}_{2}$ & $\mathrm{~S}_{3}$ & \\
\hline $\mathbf{N}_{1}$ & 15.33 & 14.60 & 14.13 & 14.68 & 41.06 & 42.95 & 44.52 & 42.84 & 61.92 & 69.86 & 71.60 & 67.79 \\
\hline $\mathbf{N}_{2}$ & 13.73 & 13.53 & 11.80 & 13.02 & 41.92 & 43.14 & 46.64 & 43.90 & 63.00 & 72.33 & 73.20 & 69.51 \\
\hline $\mathbf{N}_{3}$ & 13.46 & 12.40 & 11.66 & 12.51 & 42.70 & 44.90 & 47.07 & 44.89 & 65.88 & 74.66 & 75.00 & 71.85 \\
\hline \multirow[t]{2}{*}{ Mean } & 14.17 & 13.51 & 12.53 & 13.40 & 41.89 & 43.66 & 46.08 & 43.87 & 63.60 & 72.28 & 73.27 & 69.72 \\
\hline & \multicolumn{2}{|c|}{ S Emェ } & \multicolumn{2}{|c|}{$\mathrm{CD}$ at $5 \%$} & \multicolumn{2}{|c|}{ 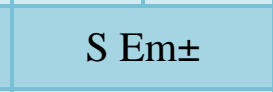 } & \multicolumn{2}{|c|}{$\mathrm{CD}$ at $5 \%$} & \multicolumn{2}{|c|}{$\mathrm{S}$ Em \pm} & \multicolumn{2}{|c|}{$\mathrm{CD}$ at $5 \%$} \\
\hline $\mathbf{S}$ & \multicolumn{2}{|c|}{0.11} & \multicolumn{2}{|c|}{0.34} & \multicolumn{2}{|c|}{0.13} & \multicolumn{2}{|c|}{0.40} & \multicolumn{2}{|c|}{1.25} & \multicolumn{2}{|c|}{3.73} \\
\hline $\mathbf{N}$ & \multicolumn{2}{|c|}{0.11} & \multicolumn{2}{|c|}{0.34} & \multicolumn{2}{|c|}{0.13} & \multicolumn{2}{|c|}{0.40} & \multicolumn{2}{|c|}{1.25} & \multicolumn{2}{|c|}{3.73} \\
\hline Interaction (S x N) & \multicolumn{2}{|c|}{0.19} & \multicolumn{2}{|c|}{0.59} & \multicolumn{2}{|c|}{0.23} & \multicolumn{2}{|c|}{0.69} & \multicolumn{2}{|c|}{2.48} & \multicolumn{2}{|c|}{7.44} \\
\hline $\begin{array}{l}\mathrm{N}_{1}=\mathrm{Ni} \\
\mathrm{N}_{2}=\mathrm{Ni} \\
\mathrm{N}_{3}=\mathrm{Ni}\end{array}$ & $\begin{array}{l}\text { trogen } c \\
\text { trogen } c \\
\text { trogen } c\end{array}$ & $\begin{array}{l}₫ 100 \mathrm{~kg} \\
\searrow 150 \mathrm{~kg} \\
\square 200 \mathrm{~kg}\end{array}$ & $g^{g} h^{-1}$ & & & & $\begin{array}{l}S_{1}=15 \\
S_{2}=25 \\
S_{3}=30\end{array}$ & $\begin{array}{l}\mathrm{cm} \times 15 \\
\mathrm{~cm} \times 15 \\
\mathrm{~cm} \times 15\end{array}$ & $\begin{array}{l}5 \mathrm{~cm} \\
5 \mathrm{~cm} \\
5 \mathrm{~cm}\end{array}$ & & & \\
\hline
\end{tabular}


Table.2 Leaf area per plant, leaf area index and total chlorophyll content as influenced by spacing, nitrogen levels and their interaction in Asiatic lily cv. Tressor under shade net condition

\begin{tabular}{|c|c|c|c|c|c|c|c|c|c|c|c|c|}
\hline \multirow[t]{3}{*}{ Nitrogen $\left(\mathbf{k g ~ h a} \mathbf{a}^{-1}\right)$} & \multicolumn{4}{|c|}{ Leaf area per plant $\left(\mathrm{cm}^{2}\right)$} & \multicolumn{4}{|c|}{ Leaf area index } & \multicolumn{4}{|c|}{ Total chlorophyll content } \\
\hline & \multicolumn{3}{|c|}{ Spacing $(\mathrm{cm})$} & \multirow[t]{2}{*}{ Mean } & \multicolumn{3}{|c|}{ Spacing $(\mathrm{cm})$} & \multirow[t]{2}{*}{ Mean } & \multicolumn{3}{|c|}{ Spacing $(\mathrm{cm})$} & \multirow[t]{2}{*}{ Mean } \\
\hline & $\mathrm{S}_{1}$ & $\mathrm{~S}_{2}$ & $\mathrm{~S}_{3}$ & & $\mathrm{~S}_{1}$ & $\mathrm{~S}_{2}$ & $\mathrm{~S}_{3}$ & & $\mathrm{~S}_{1}$ & $\mathrm{~S}_{2}$ & $\mathrm{~S}_{3}$ & \\
\hline $\mathbf{N}_{1}$ & 661.44 & 740.23 & 747.80 & 716.49 & 2.93 & 1.97 & 1.66 & 2.18 & 43.13 & 47.20 & 49.06 & 46.46 \\
\hline $\mathbf{N}_{2}$ & 671.57 & 752.96 & 758.71 & 727.75 & 2.98 & 2.00 & 1.68 & 2.22 & 44.16 & 49.23 & 51.10 & 48.16 \\
\hline $\mathbf{N}_{3}$ & 677.53 & 759.08 & 767.55 & 734.72 & 3.01 & 2.01 & 1.70 & 2.24 & 46.00 & 50.03 & 51.26 & 49.10 \\
\hline \multirow[t]{2}{*}{ Mean } & 670.18 & 750.75 & 758.02 & 726.32 & 2.97 & 1.99 & 1.68 & 2.21 & 44.43 & 48.82 & 50.47 & 47.90 \\
\hline & \multicolumn{2}{|c|}{ S Em \pm} & \multicolumn{2}{|c|}{$\mathrm{CD}$ at $5 \%$} & \multicolumn{2}{|c|}{$\mathrm{S}$ Em \pm} & \multicolumn{2}{|c|}{$\mathrm{CD}$ at $5 \%$} & \multicolumn{2}{|c|}{ S Em \pm} & \multicolumn{2}{|c|}{$\mathrm{CD}$ at $5 \%$} \\
\hline $\mathbf{S}$ & \multicolumn{2}{|c|}{2.52} & \multicolumn{2}{|c|}{7.56} & \multicolumn{2}{|c|}{0.002} & \multicolumn{2}{|c|}{0.006} & \multicolumn{2}{|c|}{0.1004} & \multicolumn{2}{|c|}{0.301} \\
\hline $\mathbf{N}$ & \multicolumn{2}{|c|}{2.52} & \multicolumn{2}{|c|}{7.56} & \multicolumn{2}{|c|}{0.002} & \multicolumn{2}{|c|}{0.006} & \multicolumn{2}{|c|}{0.1004} & \multicolumn{2}{|c|}{0.301} \\
\hline Interaction (S x N) & \multicolumn{2}{|c|}{4.98} & \multicolumn{2}{|c|}{14.93} & \multicolumn{2}{|c|}{0.003} & \multicolumn{2}{|c|}{0.01} & \multicolumn{2}{|c|}{0.17} & \multicolumn{2}{|c|}{0.521} \\
\hline
\end{tabular}

$\mathrm{N}_{1}=$ Nitrogen @ $100 \mathrm{~kg} \mathrm{ha}^{-1}$ $\mathrm{N}_{2}=$ Nitrogen@150 $\mathrm{kg} \mathrm{ha}^{-1}$ $\mathrm{N}_{3}=$ Nitrogen @ $200 \mathrm{~kg} \mathrm{ha}^{-1}$
$\mathrm{S}_{1}=15 \mathrm{~cm} \mathrm{x} 15 \mathrm{~cm}$

$\mathrm{S}_{2}=25 \mathrm{~cm} \mathrm{x} 15 \mathrm{~cm}$

$\mathrm{S}_{3}=30 \mathrm{~cm} \times 15 \mathrm{~cm}$ 
Table.3 Flowering shoots per plot and flowering shoots per $1000 \mathrm{~m}^{2}$ as influenced by spacing, nitrogen levels and their interaction in Asiatic lily cv. Tressor under shade net condition

\begin{tabular}{|c|c|c|c|c|c|c|c|c|}
\hline \multirow[t]{3}{*}{ Nitrogen $\left(\mathrm{kg} \mathrm{ha}^{-1}\right)$} & \multicolumn{4}{|c|}{ Flowering shoots per plot } & \multicolumn{4}{|c|}{ Flowering shoots per $1000 \mathrm{~m}^{2}$} \\
\hline & \multicolumn{3}{|c|}{ Spacing $(\mathrm{cm})$} & \multirow[t]{2}{*}{ Mean } & \multicolumn{3}{|c|}{ Spacing $(\mathrm{cm})$} & \multirow[t]{2}{*}{ Mean } \\
\hline & $\mathrm{S}_{1}$ & $\mathrm{~S}_{2}$ & $\mathrm{~S}_{3}$ & & $\mathrm{~S}_{1}$ & $S_{2}$ & $\mathrm{~S}_{3}$ & \\
\hline $\mathbf{N}_{1}$ & 40.66 & 50.00 & 56.33 & 49.00 & 22.59 & 27.77 & 31.29 & 27.21 \\
\hline $\mathbf{N}_{2}$ & 45.00 & 58.66 & 63.00 & 55.55 & 25.00 & 32.59 & 35.00 & 30.86 \\
\hline $\mathbf{N}_{3}$ & 51.00 & 66.00 & 70.66 & 62.55 & 28.33 & 36.66 & 39.25 & 34.74 \\
\hline \multirow[t]{2}{*}{ Mean } & 45.55 & 58.22 & 63.33 & 55.70 & 25.30 & 32.34 & 35.18 & 30.94 \\
\hline & \multicolumn{2}{|c|}{$\mathrm{S}$ Em \pm} & \multicolumn{2}{|c|}{$\mathrm{CD}$ at $5 \%$} & \multicolumn{2}{|c|}{$\mathrm{S}$ Em \pm} & \multicolumn{2}{|c|}{$\mathrm{CD}$ at $5 \%$} \\
\hline $\mathbf{S}$ & \multicolumn{2}{|c|}{0.22} & \multicolumn{2}{|c|}{0.67} & \multicolumn{2}{|c|}{0.12} & \multicolumn{2}{|c|}{0.37} \\
\hline $\mathbf{N}$ & \multicolumn{2}{|c|}{0.22} & \multicolumn{2}{|c|}{0.67} & \multicolumn{2}{|c|}{0.12} & \multicolumn{2}{|c|}{0.37} \\
\hline Interaction $(\mathbf{S} \times \mathbf{N})$ & \multicolumn{2}{|c|}{0.39} & \multicolumn{2}{|c|}{1.17} & \multicolumn{2}{|c|}{0.22} & \multicolumn{2}{|c|}{0.65} \\
\hline \multicolumn{5}{|c|}{$\begin{array}{l}\mathrm{N}_{1}=\text { Nitrogen @ } 100 \mathrm{~kg} \mathrm{ha}^{-1} \\
\mathrm{~N}_{2}=\text { Nitrogen @ } 150 \mathrm{~kg} \mathrm{ha}^{-1} \\
\mathrm{~N}_{3}=\text { Nitrogen @ } 200 \mathrm{~kg} \mathrm{ha}^{-1}\end{array}$} & \multicolumn{4}{|c|}{$\begin{array}{l}\mathrm{S}_{1}=15 \mathrm{~cm} \times 15 \mathrm{~cm} \\
\mathrm{~S}_{2}=25 \mathrm{~cm} \times 15 \mathrm{~cm} \\
\mathrm{~S}_{3}=30 \mathrm{~cm} \times 15 \mathrm{~cm}\end{array}$} \\
\hline
\end{tabular}


Among the interactions, combination of $\mathrm{S}_{3} \mathrm{~N}_{3}$ was found to show the maximum chlorophyll content (51.26) and was on par with the $\mathrm{S}_{3} \mathrm{~N}_{2}$ (51.10) while the minimum value for chlorophyll content (43.13) was recorded by $\mathrm{S}_{1} \mathrm{~N}_{1}$.

With the wider spacing and high level of nitrogen, the chlorophyll content was also increased (Ahirwar et al., 2012) in African marigold cv. Pusa Narangi Gainda under Jabalpur conditions.

The data pertaining to the effect of different levels of spacing and nitrogen on flowering shoots per plot and per $1000 \mathrm{~m}^{2}$ was presented in Table 3.

The graded levels of spacing, nitrogen and their interactions showed significant influence on the number of flowering shoots per plot (Table 3$)$. The spacing level $\mathrm{S}_{3}(30 \mathrm{~cm} \times 15$ $\mathrm{cm})$ recorded the highest number of flowering shoots per plot (63.33) and minimum number of flowering shoots per plot (45.55) was recorded by $S_{1}(15 \mathrm{~cm} \times 15 \mathrm{~cm}) . \mathrm{N}_{3}(200 \mathrm{~kg}$ $\mathrm{ha}^{-1}$ ) was best with 62.55 flowering shoots per plot whereas, $\mathrm{N}_{1}\left(100 \mathrm{~kg} \mathrm{ha}^{-1}\right)$ registered least number of flowering shoots per plot (49.00). With respect to interactions, the treatment combination of $\mathrm{S}_{3} \mathrm{~N}_{3}$ recorded the highest number of flowering shoots per plot (70.66) followed by $\mathrm{S}_{2} \mathrm{~N}_{3}$ (66.00) whereas, least number of flowering shoots per plot was recorded by $\mathrm{S}_{1} \mathrm{~N}_{1}$ (40.66).

Based on the results obtained it can be concluded that, an increase in the number of flowering shoots per plot with wider spacing might be due to less competition among the plants for nutrients, air and light as such more translocation of assimilates to the storage organs leads to maximum flower production.

The maximum number of flowering shoots per plot with application of higher nitrogen might be due to the reason that, increased flower bearing portion with respect to number of florets on the spike consequently leads to maximum flower yield (Sheoran et al., 2015). The present findings are in accordance with the earlier findings of Singh and Sangama (2000), Kawarkhe and Jane (2002) and Alan et al., (2007) in tuberose.

Regarding number of flowering shoots per $1000 \mathrm{~m}^{2}$ (Table 3), $\mathrm{S}_{3}(30 \mathrm{~cm} \times 15 \mathrm{~cm})$ recorded the highest number of flowers per $1000 \mathrm{~m}^{2}$ (35.18) and lowest number of flowering shoots per $1000 \mathrm{~m}^{2}$ was registered by $\mathrm{S}_{1}(15 \mathrm{~cm} \times 15 \mathrm{~cm})$ (25.30) whereas, highest number of flowering shoots per 1000 $\mathrm{m}^{2}$ (34.74) was recorded by highest dose of nitrogen i.e. $200 \mathrm{~kg} \mathrm{ha}^{-1}\left(\mathrm{~N}_{3}\right)$ and lowest number of flowering shoots per $1000 \mathrm{~m}^{2}$ (27.21) was recorded by $\mathrm{N}_{1}\left(100 \mathrm{~kg} \mathrm{ha}^{-1}\right)$. Among interactions, the combination of $\mathrm{S}_{3} \mathrm{~N}_{3}$ was best with highest number of flowering shoots per $1000 \mathrm{~m}^{2}$ (39.25) followed by $\mathrm{S}_{2} \mathrm{~N}_{3}$ (36.66) and least number of flowering shoots per $1000 \mathrm{~m}^{2}$ (22.59) was registered by $\mathrm{S}_{1} \mathrm{~N}_{1}$.

Based on the results obtained it can be concluded that, an increase in the number of flowering shoots per plot with wider spacing might be due to less competition among the plants for nutrients, air and light as such more translocation of assimilates to the storage organs leads to maximum flower production.

Increase in the flowering shoots with application of higher nitrogen doses might be attributed to increased metabolite transport required for growth (Marschner, 1983). These results are in agreement with the findings of Rathore and Singh (2013) in tuberose.

\section{References}

Ahirwar, M.K., Kamlesh Ahirwar., and Megha Shukla. 2012. Effect of plant densities, nitrogen and phosphorus 
levels on growth, yield and quality of African marigold. Annals of Plant and Soil Research. 14(2): 153-155.

Alan, O., Gunen, Y., Ceylan, S., and Gunen, E. 2007. Effect of nitrogen application on flower yield, some quality characteristics and leaf mineral content in tuberose (Polianthes tuberosa L.). Aegean Agricultural Research Institute. 17: 43-57.

Anonymous, 1996. International Flower Trade Show. Auction Market, Aalsmeer, Holland, 8-12 November.

Bankar, G.J., and Mukhopadhyay, J. 1990. Effect of NPK on growth and flowering in tuberose cv. Double. Indian Journal of Horticulture. 47(1): 120-126.

Chandana and Dorajeerao., A.V.D. 2014. Effect of graded levels of nitrogen and phosphorus on growth and yield of gladiolus (Gladiolus grandiflorus L.) cv. White Prosperity in coastal A.P., India. Plant Archives. 14(1): 143-150.

Das, P., Paswan, L., Chaudhary, H., Das, J., and Saikia, P. 2011. Effect of inorganic, organic and biofertilizers on yield and yield attributes of tuberose (Polinathes tuberosa Linn.). Crop Research. 42: 227-230.

Gangwar, A.P.S., Singh, J.P., Umrao, V.K., and Singh, I.P. 2012. Effect of nitrogen and phosphorus with nitrogen sources on vegetative attributes of tuberose. HortFlora Research Spectrum. 1(4): 348-353.

Jana, B.K, Roy, S. and Bose, T.K. 1974. Studies on the nutrition of ornamental plants. Effect of nutrition on growth and flowering of dahlia and tuberose. Indian Journal of Horticulture. 31(2): 182-185.

Karthikeyan, S., and Jawaharlal, M. 2013. Optimization of planting density in carnation. HortFlora Research Spectrum. 2(2): 121-125.
Kawarkhe, V.J., and Jane, R.N. 2002. Studies on nutritional requirements of tuberose (Polianthes tuberosa L.) cv. Single. Orissa Journal of Horticulture. 30: 43-46.

Khobragade, R.K., Sharad Bisen and Rajendra Singh Thakur. 2012. Effect of planting distance and pinching on growth, flowering and yield of China aster (Callistephus chinensis.) cv. Poornima. Indian Journal of Agricultural Sciences. 82 (4): 334339.

Kishore, G.R., and Singh, P.V. 2006. Effect of $\mathrm{N}, \mathrm{P}$ and $\mathrm{K}$ fertilization on vegetative growth of tuberose (Polianthes tuberosa L.) cv. Single. Plant Archives. 6: 377-378.

Kumar, S., and Singh, R.P. 1998. Effect of nitrogen, bulb size and plant density on growth, flowering and yield of tuberose (Polianthes tuberosa L.) cv. Single. Journal of Ornamental Horticulture, New Series. 1(1): 6-10.

Marschner, H. 1983. Introduction to the mineral nutrition of plants. Handbook of Plant Physiology. 15(4): 31-38.

Mukopadhyay, T.P., and Yadav, L.P. 1984. Effect of corm size, spacing on growth, flowering and corm production in gladiolus. Haryana Journal of Horticultural Sciences. 13: 95-99.

Panse, V.G., and Sukhatme, B.V. 1967. Statistical methods for agricultural workers. ICAR publication, New Delhi. 100-161.

Patel, M.M., Parmar, P.B., and Parmar, B.R. 2006. Effect of nitrogen, phosphorus and spacing on growth and flowering in tuberose (Polianthes tuberosa Linn.) cultivar Single. Journal of Ornamental Horticulture. 9(4): 286289.

Rajwal, N., and Singh, R.K. 2006. Effect of different levels of nitrogen on the 
performance of tuberose (Polianthes tuberosa L.). International Journal of Plant Science. 1: 111-112.

Ram, M., Pal, V., Singh, M.K., and Kumar, M. 2012. Response of different spacing and salicylic acid levels on growth and flowering of gladiolus (Gladiolus grandiflora L.). HortFlora Research Spectrum. 1(3): 270-273.

Rathore, A.C., and Singh, J.N. 2013. Effect of graded levels of nitrogen on production of flower, oil and bulb of tuberose (Polianthes tuberosa L.). HortFlora Research Spectrum. 2(1): 60-63.

Sheoran, S.O.P., Dudi, B.S., Beniwal and Dalal, R.P.S. 2015. Effect of nitrogen and spacing on growth and yield of tuberose cv. Prajwal. Annals of AgriBio Research. 20(2): 212-215.

Shiraz, A., and Maurya, K.R. 2005. Effect of spacing and corm size on growth, flowering and corm production in gladiolus. Indian journal of Horticulture. 62(1): 95-96.

Singh, K.P., and Sangama. 2000. Effect of planting densities on growth, flowering and post-harvest quality of cut spike in tuberose (Polianthes tuberosa L.) cv. Single. Journal of
Applied Horticulture. 2: 54-55.

Singh, P.V., and Kumar, M. 1999. Effect of spacing, depth and time of planting on growth, flowering and bulb production of tuberose cv. Double. Journal of Ornamental Horticulture. 2(2): 127130.

Singh, S.K., and Singh, R.K. 2005. Combined effect of Nitrogen and spacing on tuberose cv. Double. Progressive Agriculture. 5(1\&2): 70-73.

Sudhakar, M., and Kumar, R.S. 2012. Effect of corm size and spacing on growth and flowering of gladiolus $\mathrm{cv}$. White Friendship. International Journal of Current Agricultural Sciences. 2(6): 912.

Tisdale, S.L., and Nelson, W.L. 1975. Soil fertility and fertilizers $3^{\text {rd }}$ ed. Macmillan Publishing Co., Inc. New york.

Vedavathi, R.S., Manjunatha, B., Basavanagowda, M.G., Thipanna, K.S., and Ravishankar M. Patil. 2014. Effect of spacing and nitrogen levels on quantity and quality characteristics of Asiatic lily. HortFlora Research Spectrum. 3(4): 339-343.

\section{How to cite this article:}

Swetha, J., T. Suseela, A.V.D. Dorajeerao, D.R. Salomi Suneetha and Sujatha, R.V. 2018. Effect of Spacing and Nitrogen on Vegetative Growth and Flower Yield of Asiatic Lily CV. Tressor under Shade Net Condition. Int.J.Curr.Microbiol.App.Sci. 7(08): 4800-4809. doi: https://doi.org/10.20546/ijcmas.2018.708.505 